\title{
Single high-dose buprenorphine for opioid craving during withdrawal
}

\author{
Jamshid Ahmadi ${ }^{*}$, Mina Sefidfard Jahromi ${ }^{1}$, Dara Ghahremani ${ }^{2}$ and Edythe D. London ${ }^{2,3,4}$
}

\begin{abstract}
Background: Opioid use disorder is one of the most prevalent addiction problems worldwide. Buprenorphine is used as a medication to treat this disorder, but in countries where buprenorphine is unavailable in combination with naloxone, diversion can be a problem if the medication is given outside a hospital setting.

Objective: The objective of this research is to evaluate the effect of a single, high dose of buprenorphine on craving in opioid-dependent patients over 5 days of abstinence from use of other opioids. The primary goal was to determine the safety and efficacy of buprenorphine during withdrawal in a hospital setting.

Methods: Ninety men who used opium, heroin, or prescribed opioids and met DSM-5 criteria for opioid use disorder (severe form) were randomized to three groups ( $n=30$ per group) to receive a single, sublingual dose of buprenorphine $(32,64$, or $96 \mathrm{mg})$. The study was conducted in an inpatient psychiatric ward, with appropriate precautions and monitoring of respiratory and cardiovascular measures. Buprenorphine was administered when the patients were in moderate opiate withdrawal, as indicated by the presence of four to five symptoms. A structured clinical interview was conducted, and urine toxicology testing was performed at baseline. Self-reports of craving were obtained at baseline and on each of the 5 days after buprenorphine administration.
\end{abstract}

Findings: Craving decreased from baseline in each of the three groups $(p<0.0001)$, with a significant interaction between group and time $(p<0.038)$, indicating that groups with higher doses of buprenorphine had greater reduction.

Conclusions: A single, high dose of buprenorphine can reduce craving during opioid withdrawal; additional studies with follow-up are warranted to evaluate safety.

Keywords: Buprenorphine, Craving, Opioid dependence, Opioid withdrawal

\section{Background}

Buprenorphine, a partial agonist at mu-opioid receptors and an antagonist at delta- and kappa-opioid receptors, has been evaluated for the management of opioid use disorder [1-13]. Regarded as safer than methadone [57], buprenorphine at a dose of $8 \mathrm{mg}$ is as effective as 60 $\mathrm{mg}$ of methadone [8]. Buprenorphine is well absorbed after sublingual administration $[4,9,10]$, and its partial agonist action at mu-opioid receptors contributes to a safer profile of buprenorphine over methadone, with minimal respiratory depressant effects [14-26].

The purpose of this study was to assess the effects of single, high-dose buprenorphine administration (32,

\footnotetext{
* Correspondence: Jamshid_Ahmadi@yahoo.com

${ }^{1}$ Substance Abuse Research Center, Shiraz University of Medical Sciences, Shiraz, Iran

Full list of author information is available at the end of the article
}

64, or $96 \mathrm{mg}$ ) on opiate craving during initial abstinence. Craving is an essential feature of substance use disorders, as evidenced by its recent addition to the diagnostic criteria for these disorders in the Diagnostic and Statistical Manual of Mental Disorders, Fifth Edition (DSM-5; American Psychiatric Association) [3, $17,20,21]$, and it persists after detoxification to promote relapse $[3,17,21,22]$. Buprenorphine was administered in a hospital setting to reduce the possibility of diversion of the medication, which is much more likely if the formulation does not include naloxone, which is included in some formulations for this purpose (e.g., Suboxone ${ }^{\circ}$. Such combined formulations are not available in Iran.

Doses of buprenorphine higher than those that are commonly administered clinically (i.e., $16-24 \mathrm{mg}$ ) were used to increase the effective half-life of the medication

(c) The Author(s). 2018 Open Access This article is distributed under the terms of the Creative Commons Attribution 4.0 International License (http://creativecommons.org/licenses/by/4.0/), which permits unrestricted use, distribution, and 
(the plasma elimination half-life of buprenorphine is $36-72 \mathrm{~h}$ after sublingual use) and to enhance mu-opioid receptor occupancy. A single high dose was examined because repeated buprenorphine administration in outpatients increases the possibility of dependence, diversion, and abuse (this is also based on our clinical experiences in Iran) [3, 18, 21, 22, 27, 28]. Buprenorphine was administered rather than methadone due to the risk of overdose with a single, high dose of methadone [22-24]. Common practice in our center is for opioid-dependent patients to undergo withdrawal as inpatients under supervision, to leave the hospital after detoxification without medication-assisted treatment, and then to return for psychosocial follow-up. If a patient requires medication when evaluated at follow-up, appropriate management, such as buprenorphine maintenance treatment, is initiated.

\section{Methods and materials}

\section{Participants and procedures}

This study was approved and monitored by the Committee of Ethics of Shiraz University of Medical Sciences; it adhered to the Declaration of Helsinki Ethical Principles for Medical Research Involving Human Subjects. At screening, participants were interviewed and examined for eligibility by a board certified psychiatrist. We explained the goals of the study, and guaranteed confidentiality. All the patients gave written informed consent prior to entering the study. The participants were male inpatients at the main psychiatric ward, where only men were hospitalized. Prior to admission, they had been abusing opium, heroin, and illicit or prescribed opioids for at least 1 year. Patients who met initial eligibility requirements on screening were administered the Structured Clinical Interview for DSM-5, Clinical Version (SCID-I), by a board certified psychiatrist to determine if they met the criteria for opioid use disorder (listed in DSM-5). Daily opioid abuse for at least 1 year was a requirement. Patients were excluded if they had substance use disorders involving drugs other than opioids (excluding tobacco), organic mental disorders, major medical diseases (hepatic, renal, cardiovascular, pulmonary, gastrointestinal, or malignant diseases), or any type of psychosis. The study was a double-blind randomized trial. The first 90 eligible treatment-seeking patients who referred to our ward were randomly assigned to the three buprenorphine arms ( $n=30$ per group).

Buprenorphine tablets (a single dose) were administered sublingually, while the patient was in moderate opioid withdrawal from opioids, as indicated by the presence of four or five symptoms of opioid withdrawal [3]. The buprenorphine doses tested were $32 \mathrm{mg}$, which is the maximum dosage currently used clinically, and two other doses that were twice and three times as much, respectively. The interview, examination, and questioning were performed at the treatment hospital. To enhance confidentiality and validity of the information, data were obtained from the patient in the absence of accompanying family or acquaintances.

A visual analog scale (VAS) that has been used previously [16-19] was used to measure the opioid craving, with a range of $0-10(0=$ no craving and $10=$ severe desire, craving, or temptation all the time). Patients responded to the statement: Rate your craving over the past day. Measurements of craving were taken each morning. The hospital system covered sublingual tablets. Patients did not receive any form of compensation. During the hospitalization course, they did not receive any other methods of coping with craving (e.g., group sessions focused on relaxation/mindfulness/distraction, etc.).

A placebo group was not included because of the high possibility of severe withdrawal without active pharmacological treatment. The pills had the same shape and color. They were given in 8-mg increments. Everyone received the same number of pills. Placebo pills were used so that the patients did not know what dose they were receiving. Tablets were administered based on the tolerance of the patient.

Out of 90 patients, each group (30 patients) received $32 \mathrm{mg}, 64 \mathrm{mg}$, or $96 \mathrm{mg}$ of buprenorphine. Over the next 5 days, craving and adverse effects were evaluated. The degree of opioid craving was calculated and assessed through patients' reports. Urine drug toxicology was carried out using thin-layer chromatography (TLC) before administration of the single dose, twice a week and at the end of the 5-day trial. To ensure safety, adverse effects, vital signs, respiration, and gastrointestinal effects were monitored every hour for the first day, and then every $6 \mathrm{~h}$. For the current study, withdrawal was done in the hospital because we administered "high doses" instead of standard doses. We advocate using a single dose on an inpatient basis and then discharging the patients drug-free (without medication assistance treatment) and with an appointment for close psychosocial follow-up [2, 18, 20]. In any follow-up, if a patient needs medication, we start appropriate treatment such as buprenorphine maintenance treatment.

\section{Data analysis}

Statistical analyses included both inferential and descriptive statistical methods. Data analysis was conducted using SPSS version 21. A repeated-measures two-way analysis of variance (ANOVA) was used, with day and group as the two factors and Greenhouse-Geisser correction for violation of sphericity. Post hoc $t$ tests of differences in means were performed, and chi-square testing was used to test for differences in frequencies among the groups. The threshold for statistical significance was $p<0.05$, both tails. 


\section{Results}

Data were collected from 90 men whose mean age was $32.85 \pm 6.97$ years. All the patients whom were screened entered the research study, and all of those who entered completed the trial (Fig. 1and Table 1). During the course of the study, no illicit opioid use was detected (based on daily interview and urine toxicology). All the patients had normal liver and kidney function before enrollment.

The Consolidated Standards of Reporting Trials (CONSORT) flow and the checklist for the study are shown in Fig. 1 and Table 1.

The three groups did not differ on demographic characteristics (Table 2). Table 3 presents craving scores of the three groups during the 5-day interval of treatment. A significant main effect of day $(F(2,2.16)=199.96, p<$ $0.0001)$ but not group $(F(2,87)=1.67, p=0.194)$ and a significant group-by-day interaction $(F(2,4.32)=2.52$, $p<$ 0.05) were found.

Post hoc $t$ tests revealed that the 32-mg group differed significantly from both the 64-mg and 96-mg groups, with lower craving observed for the higher dose groups. No significant differences were observed between the 64-mg and 96-mg groups, suggesting that the maximal effect on craving reduction was achieved with the 64-mg dose (Table 4).

\section{Adverse effects}

To ensure safety, side effects, vital signs, respiration, and gastrointestinal effects were measured and monitored every hour for the first day, and then every $6 \mathrm{~h}$. Nine patients developed notable side effects. Two (both in the 96-mg group) developed significant hypotension (blood pressure of $75 / 50$ and $80 / 45$, respectively) and were treated with hydration. Two (both in the 32-mg group) developed nausea. Five (two in the 64-mg group and three in the 96-mg group) developed both nausea and vomiting. Patients who had nausea or vomiting were treated with antiemetic medications. No severe respiratory, cardiovascular, or gastrointestinal adverse effects were observed.

\section{Discussion}

Buprenorphine has been evaluated extensively for the treatment of opioid use disorder [2-4]. In chronic use, it is considered for reducing craving and increasing long-term abstinence from illicit opioids [8].

Here we show that a single dose of buprenorphine (32 $\mathrm{mg}, 64 \mathrm{mg}$, and $96 \mathrm{mg}$ ) can provide a rapid, effective, and safe means of reducing opioid craving at 5 days post-treatment, $64 \mathrm{mg}$ more so than $32 \mathrm{mg}$, with no greater effect at $96 \mathrm{mg}$. The comparable efficacy of the

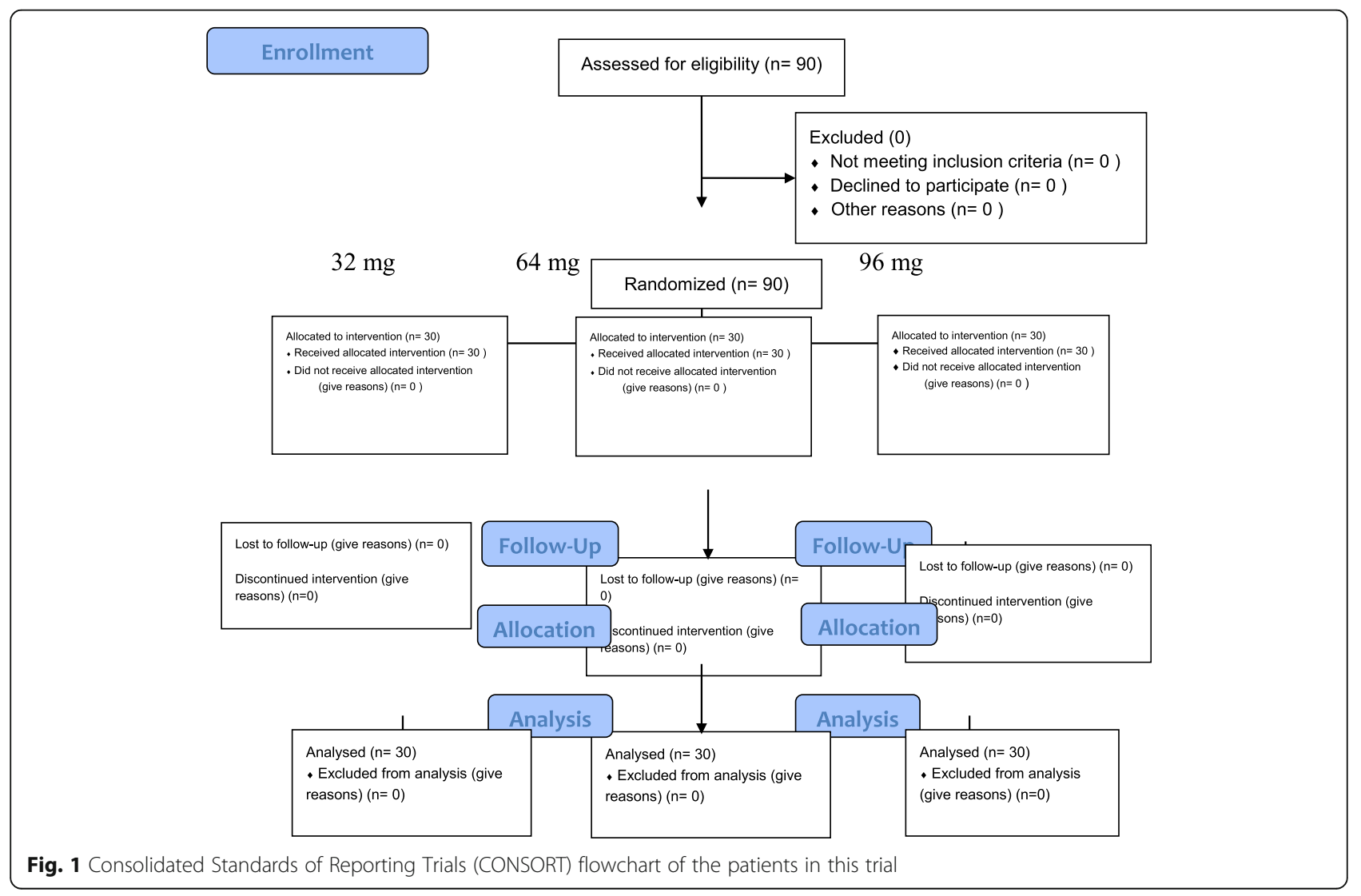


Table 1 CONSORT 2010 checklist of information to include when reporting a randomized trial

\begin{tabular}{|c|c|c|c|}
\hline Section/topic & Item no. & Checklist item & $\begin{array}{l}\text { Reported on } \\
\text { page no. }\end{array}$ \\
\hline \multicolumn{4}{|l|}{ Title and abstract } \\
\hline & $1 a$ & Identification as a randomized trial in the title & 1 \\
\hline & $1 b$ & $\begin{array}{l}\text { Structured summary of trial design, methods, } \\
\text { results, and conclusions (for specific guidance } \\
\text { see CONSORT for abstracts) }\end{array}$ & 1 \\
\hline \multicolumn{4}{|l|}{ Introduction } \\
\hline \multirow[t]{2}{*}{ Background and objectives } & $1 a$ & Scientific background and explanation of rationale & 2 \\
\hline & $2 b$ & Specific objectives or hypotheses & 2 \\
\hline \multicolumn{4}{|l|}{ Methods } \\
\hline \multirow[t]{2}{*}{ Trial design } & $2 a$ & $\begin{array}{l}\text { Description of trial design (such as parallel, factorial) } \\
\text { including allocation ratio }\end{array}$ & 2 \\
\hline & $2 b$ & $\begin{array}{l}\text { Important changes to methods after trial } \\
\text { commencement (such as eligibility criteria), } \\
\text { with reasons }\end{array}$ & 2 \\
\hline \multirow[t]{2}{*}{ Participants } & $2 a$ & Eligibility criteria for participants & 2 \\
\hline & $2 b$ & $\begin{array}{l}\text { Settings and locations where the data were } \\
\text { collected }\end{array}$ & 2 \\
\hline Interventions & 2 & $\begin{array}{l}\text { The interventions for each group with sufficient } \\
\text { details to allow replication, including how and } \\
\text { when they were actually administered }\end{array}$ & 2 \\
\hline \multirow[t]{2}{*}{ Outcomes } & $2 a$ & $\begin{array}{l}\text { Completely defined pre-specified primary and } \\
\text { secondary outcome measures, including how } \\
\text { and when they were assessed }\end{array}$ & 2 \\
\hline & $2 b$ & $\begin{array}{l}\text { Any changes to trial outcomes after the trial } \\
\text { commenced, with reasons }\end{array}$ & 2 \\
\hline \multirow[t]{2}{*}{ Sample size } & $2 a$ & How sample size was determined & 2 \\
\hline & $2 b$ & $\begin{array}{l}\text { When applicable, explanation of any interim } \\
\text { analyses and stopping guidelines }\end{array}$ & NA \\
\hline \multicolumn{4}{|l|}{ Randomization: } \\
\hline \multirow[t]{2}{*}{ Sequence generation } & $2 a$ & $\begin{array}{l}\text { Method used to generate the random allocation } \\
\text { sequence }\end{array}$ & 2 \\
\hline & $2 b$ & $\begin{array}{l}\text { Type of randomization; details of any restriction } \\
\text { (such as blocking and block size) }\end{array}$ & 2 \\
\hline Allocation concealment mechanism & 2 & $\begin{array}{l}\text { Mechanism used to implement the random } \\
\text { allocation sequence (such as sequentially } \\
\text { numbered containers), describing any steps } \\
\text { taken to conceal the sequence until interventions } \\
\text { were assigned }\end{array}$ & 2 \\
\hline Implementation & 2 & $\begin{array}{l}\text { Who generated the random allocation sequence, } \\
\text { who enrolled participants, and who assigned } \\
\text { participants to interventions }\end{array}$ & 2 \\
\hline \multirow[t]{2}{*}{ Blinding } & $2 \mathrm{a}$ & $\begin{array}{l}\text { If done, who was blinded after assignment to } \\
\text { interventions (for example, participants, care } \\
\text { providers, those assessing outcomes) and how }\end{array}$ & 2 \\
\hline & $2 b$ & If relevant, description of the similarity of interventions & NA \\
\hline \multirow[t]{2}{*}{ Statistical methods } & $2 a$ & $\begin{array}{l}\text { Statistical methods used to compare groups for } \\
\text { primary and secondary outcomes }\end{array}$ & 2 \\
\hline & $2 b$ & $\begin{array}{l}\text { Methods for additional analyses, such as subgroup } \\
\text { analyses and adjusted analyses }\end{array}$ & 2 \\
\hline \multicolumn{4}{|l|}{ Results } \\
\hline $\begin{array}{l}\text { Participant flow (a diagram is } \\
\text { strongly recommended) }\end{array}$ & $3 a$ & $\begin{array}{l}\text { For each group, the numbers of participants who } \\
\text { were randomly assigned, received intended treatment, } \\
\text { and were analyzed for the primary outcome }\end{array}$ & 2 \\
\hline
\end{tabular}


Table 1 CONSORT 2010 checklist of information to include when reporting a randomized trial (Continued)

\begin{tabular}{|c|c|c|c|}
\hline Section/topic & Item no. & Checklist item & $\begin{array}{l}\text { Reported on } \\
\text { page no. }\end{array}$ \\
\hline & $3 b$ & $\begin{array}{l}\text { For each group, losses and exclusions after } \\
\text { randomization, together with reasons }\end{array}$ & 3 \\
\hline \multirow[t]{2}{*}{ Recruitment } & $3 a$ & $\begin{array}{l}\text { Dates defining the periods of recruitment } \\
\text { and follow-up }\end{array}$ & 3 \\
\hline & $3 b$ & Why the trial ended or was stopped & 3 \\
\hline Baseline data & 3 & $\begin{array}{l}\text { A table showing baseline demographic and } \\
\text { clinical characteristics for each group }\end{array}$ & 3 \\
\hline Numbers analyzed & 3 & $\begin{array}{l}\text { For each group, number of participants } \\
\text { (denominator) included in each analysis and } \\
\text { whether the analysis was by original assigned } \\
\text { groups }\end{array}$ & 3 \\
\hline \multirow[t]{2}{*}{ Outcomes and estimation } & $3 a$ & $\begin{array}{l}\text { For each primary and secondary outcome, results } \\
\text { for each group, and the estimated effect size and } \\
\text { its precision (such as } 95 \% \text { confidence interval) }\end{array}$ & 3 \\
\hline & $3 b$ & $\begin{array}{l}\text { For binary outcomes, presentation of both absolute } \\
\text { and relative effect sizes is recommended }\end{array}$ & 3 \\
\hline Ancillary analyses & 3 & $\begin{array}{l}\text { Results of any other analyses performed, including } \\
\text { subgroup analyses and adjusted analyses, } \\
\text { distinguishing pre-specified from exploratory }\end{array}$ & 3 \\
\hline Harms & 3 & $\begin{array}{l}\text { All important harms or unintended effects in each } \\
\text { group (for specific guidance see CONSORT for harms) }\end{array}$ & 3 \\
\hline \multicolumn{4}{|l|}{ Discussion } \\
\hline Limitations & 6 & $\begin{array}{l}\text { Trial limitations, addressing sources of potential bias, } \\
\text { imprecision, and, if relevant, multiplicity of analyses }\end{array}$ & 3 \\
\hline Generalizability & 6 & $\begin{array}{l}\text { Generalizability (external validity, applicability) of } \\
\text { the trial findings }\end{array}$ & 6 \\
\hline Interpretation & 6 & $\begin{array}{l}\text { Interpretation consistent with results, balancing benefits } \\
\text { and harms, and considering other relevant evidence }\end{array}$ & 6 \\
\hline \multicolumn{4}{|l|}{ Other information } \\
\hline Registration & 6 & Registration number and name of trial registry & 6 \\
\hline Protocol & 6 & Where the full trial protocol can be accessed, if available & 6 \\
\hline Funding & 6 & $\begin{array}{l}\text { Sources of funding and other support (such as supply of } \\
\text { drugs), role of funders }\end{array}$ & 6 \\
\hline
\end{tabular}

Table 2 Demographic characteristics of the patients

\begin{tabular}{|c|c|c|c|c|c|c|c|c|c|}
\hline \multicolumn{2}{|l|}{ Group } & $\begin{array}{l}32 \mathrm{mg} \\
n=30(33.33 \%)\end{array}$ & $\begin{array}{l}64 \mathrm{mg} \\
n=30(33.33 \%)\end{array}$ & $\begin{array}{l}96 \mathrm{mg} \\
n=30(33.33 \%)\end{array}$ & $\begin{array}{l}\text { Total } \\
n=90(100 \%)\end{array}$ & Chi-square & $F$ & df & $p$ value $^{a}$ \\
\hline \multicolumn{2}{|c|}{ Age (years) "M (SD)." } & $34.20 \pm 7.30$ & $32.83 \pm 8.16$ & $31.53 \pm 5.035$ & $32.85 \pm 6.97$ & & 1.10 & 2 & 0.337 \\
\hline \multicolumn{2}{|c|}{ Drug abuse (years) "M (SD)." } & $9.75 \pm 5.86$ & $9.43 \pm 6.52$ & $10.50 \pm 6.29$ & $9.89 \pm 6.17$ & & 0.232 & 2 & 0.794 \\
\hline \multirow{3}{*}{$\begin{array}{l}\text { Jobc } \\
\text { "n (\%)" }\end{array}$} & Unemployed & $12(40)$ & $19(63.3)$ & $14(40)$ & $43(47.8)$ & 8.719 & & 6 & 0.190 \\
\hline & Employed & $2(6.7)$ & $3(10.0)$ & $2(6.7)$ & $7(7.8)$ & & & & \\
\hline & Self-employed & $16(53.3)$ & $7(23.3)$ & $16(53.3)$ & $39(43.3)$ & & & & \\
\hline \multirow{4}{*}{$\begin{array}{l}\text { Educationc } \\
\text { "n (\%)" }\end{array}$} & Unable to read/write & $1(3.3)$ & $1(3.3)$ & $0(0)$ & $2(2.2)$ & 4.918 & & 8 & 0.766 \\
\hline & Primary school & $11(36.7)$ & $8(26.7)$ & $10(33.3)$ & $29(32.2)$ & & & & \\
\hline & High school & $12(40)$ & $17(56.7)$ & $15(50)$ & $44(48.9)$ & & & & \\
\hline & University education & $6(20)$ & $4(13.3)$ & $4(13.3)$ & $14(15.6)$ & & & & \\
\hline \multirow{2}{*}{$\begin{array}{l}\text { Marital status } \\
\text { "n (\%)" }\end{array}$} & Married & $15(50)$ & $21(70)$ & $14(46.7)$ & $50(55.6)$ & 3.870 & & 2 & 0.144 \\
\hline & Single & $15(50)$ & $9(30)$ & $16(53.3)$ & $40(44.4)$ & & & & \\
\hline
\end{tabular}

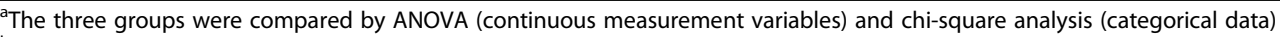

${ }^{b}$ Numbers tabulated indicate means \pm standard deviation (SD)

${ }^{\mathrm{c}}$ Numbers tabulated indicate how many participants were in each category 
Table 3 Craving scores (means and standard deviations) of the three groups

\begin{tabular}{llll}
\hline Group (Buprenorphine, mg) & 32 & 64 & 96 \\
Day & $n=30$ & $n=30$ & $n=30$ \\
\hline Baseline & $7.23 \pm 3.51$ & $6.93 \pm 3.54$ & $7.56 \pm 3.53$ \\
Day 1 & $4.46 \pm 3.95$ & $4.96 \pm 2.90$ & $4.00 \pm 2.75$ \\
Day 2 & $2.56 \pm 3.23$ & $3.03 \pm 2.23$ & $1.00 \pm 1.74$ \\
Day 3 & $1.70 \pm 2.39$ & $0.900 \pm 1.37$ & $0.366 \pm 0.927$ \\
Day 4 & $1.23 \pm 1.86$ & $0.300 \pm 0.749$ & $0.233 \pm 0.727$ \\
Day 5 & $0.700 \pm 1.14$ & $0.100 \pm 0.402$ & $0.00 \pm 0.00$ \\
\hline
\end{tabular}

64- and 96-mg dosages may reflect occupancy of mu-opioid receptors to the same degree over the short (5 days) post-treatment evaluation time. Doses higher than 16-24 mg are thought to increase the effective half-life of buprenorphine; therefore, high doses $(64 \mathrm{mg}$ and $96 \mathrm{mg}$ ) would be expected to be more effective than $32 \mathrm{mg}$, as observed here.

Administration of buprenorphine as a single large dose decreases concerns about compliance as well as the probability of dependence, diversion, and abuse. Moreover, cost considerations are favorable, especially when considering administration to outpatients without hospitalization. A single-dose treatment also is suited to transition to antagonist treatment, which could probably be started at an earlier time than with a traditional detoxification schedule lasting many days or even weeks. Moreover, it could also provide a more suitable titration of agonist treatment, potentially with lower maintenance doses being required. In patients who are unsuitable for or decline medication -assisted treatment, it would allow more rapid referral to either an intensive outpatient or residential treatment program.

Strengths of this study included the randomized clinical trial design and a reasonable number of patients, carefully diagnosed using DSM-5 criteria and urine drug screening tests. However, the study had some limitations, including its recruitment of men only. It would be important to know if the results are generalizable to both sexes and to determine the duration of the effect of single-dose buprenorphine on opioid craving. Administration of a high dose of buprenorphine may be far more likely to result in respiratory or cardiovascular complications in older patients

Table 4 Post hoc $t$ test $p$ values of the three groups

\begin{tabular}{lllllll}
\hline Group & $\begin{array}{l}\text { Baseline } \\
p \text { value }\end{array}$ & $\begin{array}{l}\text { Day 1 } \\
p \text { value }\end{array}$ & $\begin{array}{l}\text { Day 2 } \\
p \text { value }\end{array}$ & $\begin{array}{l}\text { Day 3 } \\
p \text { value }\end{array}$ & $\begin{array}{l}\text { Day 4 } \\
p \text { value }\end{array}$ & $\begin{array}{l}\text { Day 5 } \\
p \text { value }\end{array}$ \\
\hline 32 vs 64 & 0.743 & 0.553 & 0.469 & 0.069 & 0.004 & 0.001 \\
32 vs 96 & 0.716 & 0.579 & 0.017 & 0.003 & 0.002 & 0.000 \\
64 vs 96 & 0.489 & 0.252 & 0.002 & 0.223 & 0.835 & 0.583 \\
\hline
\end{tabular}

with underlying occult disorders, especially sleep apnea, than in younger patients.

\section{Conclusions}

The single-dose buprenorphine treatment provided safe and rapid treatment of opioid craving. The outcomes support further investigations of the use of a single high dose of buprenorphine as a safe and effective protocol to early treatment of these patients. Moreover, the findings support further investigations of a single dose to decrease opioid craving over more extended time frames.

Abbreviations

DSM-5: Diagnostic and Statistical Manual of Mental Disorders, Fifth Edition; RCT: Randomized clinical trial; VAS: Visual analog scale

\section{Acknowledgements}

This research study was a section of a proposal approved by the Ethics Research Committee of Shiraz University of Medical Sciences

(IRCT2016071325160N4), and it was granted by the Vice Chancellery for Research, Shiraz University of Medical Sciences, Shiraz, Iran. Funding for the efforts of Drs. London and Ghahremani was provided by the Thomas P. and Katherine K. Chair of Addiction Studies and the Margaret Greene Family Trust.

\section{Availability of data and materials}

Yes

\section{Authors' contributions}

JA proposed the idea, wrote the proposal, and drafted the manuscript; MS collected the data and assisted in writing the manuscript; DG and EL contributed to data analysis and interpretation and finalizing of the manuscript. All authors read and approved the final manuscript.

\section{Ethics approval and consent to participate}

Professor Hashemi Vice chancellor for research, Shiraz University of Medical Sciences verified ethical approval for the study. Informed consent has been obtained from all participants.

\section{Consent for publication}

The patients in the study have agreed to the publication of their data.

Competing interests

The authors declare that they have no competing interests.

\section{Publisher's Note}

Springer Nature remains neutral with regard to jurisdictional claims in published maps and institutional affiliations.

\section{Author details}

${ }^{1}$ Substance Abuse Research Center, Shiraz University of Medical Sciences, Shiraz, Iran. ${ }^{2}$ Department of Psychiatry and Biobehavioral Sciences, University of California at Los Angeles, Los Angeles, California, USA. ${ }^{3}$ Department of Molecular and Medical Pharmacology, University of California at Los Angeles, Los Angeles, California, USA. ${ }^{4}$ Brain Research Institute, University of California at Los Angeles, Los Angeles, California, USA.

Received: 16 August 2018 Accepted: 14 November 2018

Published online: 10 December 2018

\section{References}

1. Walsh SL, Preston KL, Stitzer ML, Cone EJ, Bigelow GE. Clinical pharmacology of buprenorphine: ceiling effects at high doses. Clin Pharmacol Ther. 1994;55: 569-80. https://doi.org/10.1038/clpt.1994.71.

2. Jonnes J. The rise of the modern addict. Am J Public Health. 1995:85:1157-62.

3. Sadock B, Sadock V, Ruiz P, editors. Kaplan \& Sadock's synopsis of psychiatry. Philadelphia: Lippincott Williams \& Wilkins; 2015. 
4. Jasinski DR, Pevnick JS, Griffith JD. Human pharmacology and abuse potential of the analgesic buprenorphine: a potential agent for treating narcotic addiction. Arch Gen Psychiatry. 1978;35:501-16.

5. Ling W, Charuvastra C, Collins JF, Batki S, Brown LS Jr, Kintaudi P, Wesson DR, McNicholas L, Tusel DJ, Malkerneker U, Renner JA Jr, Santos E, Casadonte P, Fye C, Stine S, Wang RI, Segal D. Buprenorphine maintenance treatment of opiate dependence: a multicenter randomized clinical trial. Addiction. 1998:93:475-86.

6. Ling W, Rawson RA, Compton MA. Substitution pharmacotherapies for opioid addiction: from methadone to LAAM and buprenorphine. J Psychoactive Drugs. 1994;26:119-28.

7. Strain EC, Stitzer ML, Liebson IA, Bigelow GE. Comparison of buprenorphine and methadone in the treatment of opioid dependence. Am J Psychiatry. 1994;151:1025-30.

8. Johnson RE, Jaffe JH, Fudala PJ. A controlled trial of buprenorphine treatment for opioid dependence. J Am Med Assoc. 1992;267:2750-5.

9. Lewis JW. Buprenorphine. Drug Alcohol Depend. 1985;14:363-72.

10. Jasinski DR, Fudala PJ, Johnson RE. Sublingual versus subcutaneous buprenorphine in opiate abusers. Clin Pharmacol Ther. 1989;45:513-9.

11. Martin WR, Evades CG, Thompson JA, Suppler RE, Gilbert PE. The effects of morphine- and nalorphinelike drugs in the non-dependent and morphine dependent chronic spinal dog. J Pharmacol Exp Ther. 1976; 197:517-32

12. Cowan A, Lewis JW, MacFarlane IR. Agonist and antagonist properties of buprenorphine: a new antinociceptive agent. Br J Pharmacol. 1977;60:537-45.

13. Negus SS, Dykstra LA. Kappa antagonist properties of buprenorphine in the shock titration procedure. Eur J Pharmacol. 1988;156:77-86.

14. Leander JD. Buprenorphine is a potent K-opioid receptor antagonist in pigeons and mice. Eur J Pharmacol. 1988;151:457-61.

15. Ariens EJ. Intrinsic activity: partial agonists and partial antagonists. J Cardiovasc Pharmacol. 1983;5:S8-15.

16. Ahmadi J, Sahraian A, Dastgheib SA, Moghimi E, Bazrafshan A. Treatment of heroin abuse. Sch Acad J Biosci. 2015;3(11):966-8.

17. Ahmadi J, Razeghian Jahromi L. Comparing the effect of buprenorphine and methadone in the reduction of methamphetamine craving: a randomized clinical trial. Trials. 2017;18(1):259. https://doi.org/10.1186/ s13063-017-2007-3.1038/clpt.1994.71.

18. Ahmadi J, Sefidfard Jahromi M. Fast effect of buprenorphine on opioiddependent patients with suicidal ideation: a novel approach. Int J High Risk Behav Addict. 2018;7(2):e57510. https://doi.org/10.5812/ijhrba.57510.

19. McHugh RK, Fitzmaurice GM, Carroll KM, Griffin ML, Hill KP, Wasan AD, Weiss RD. Assessing craving and its relationship to subsequent prescription opioid use among treatment-seeking prescription opioid dependent patients. Drug Alcohol Depend. 2014;0:121-6. https://doi.org/10.1016/j.drugalcdep.2014.10.002.

20. Ahmadi J. The effect of buprenorphine on the reduction of cannabis and heroin craving and suicidal thoughts: a new finding. Insights Biomed. 2016;1:2.

21. Gerra G, Leonardi C, D'Amore A, Strepparola G, Fagetti R, Assi C, Lucchini A. Buprenorphine treatment outcome in dually diagnosed heroin dependent patients: a retrospective study. Prog NeuroPsychopharmacol Biol Psychiatry. 2006;30(2):265-72.

22. Maremmani AGl, Rovai L, Pani PP, Pacini M, Lamanna F, Rugani F, Maremmani I. Do methadone and buprenorphine have the same impact on psychopathological symptoms of heroin addicts? Ann Gen Psychiatry. 2011;10(1):1.

23. Manglik A, Kruse AC, Kobilka TS, Thian FS, Mathiesen JM, Sunahara RK, Pardo L, Weis WI, Kobilka BK, Granier S. Crystal structure of the micro-opioid receptor bound to a morphinan antagonist. Nature. 2012;485:321-6.

24. Huang W, Manglik A, Venkatakrishnan AJ, Laeremans T, Feinberg EN, Sanborn AL, Kato HE, Livingston KE, Thorsen TS, Kling RC, Granier S, Gmeiner P, Husbands SM, Traynor JR, Weis WI, Steyaert J, Dror RO, Kobilka BK. Structural insights into micro-opioid receptor activation. Nature. 2015;524:315-21.

25. Ahmadi J, Sefidfard M. Anxiety treatment of opioid dependent patients with buprenorphine: a randomized, double-blind, clinical trial. Indian J Psychol Med. 2017;39:445-9.

26. Ahmadi J, Sefidfard Jahromi M. Ultrarapid influence of buprenorphine on major depression in opioid-dependent patients: a double blind, randomized clinical trial. Subst Use Misuse. 2017:1-4. https://doi.org/10.1080/10826084. 2017.1400063 [Epub ahead of print] PMID: 29148881
27. Ahmadi J, Ahmadi K, Ohaeri J. Controlled, randomized trial in maintenance treatment of intravenous buprenorphine dependence with naltrexone, methadone or buprenorphine: a novel study. Eur J Clin Invest. 2003:33(9):824-9.

28. Ahmadi J, Maany I, Ahmadi M. Treatment of intravenous buprenorphine dependence: a randomized open clinical trial. Ger J Psychiatry. 2003;6:23-9.

\section{Ready to submit your research? Choose BMC and benefit from:}

- fast, convenient online submission

- thorough peer review by experienced researchers in your field

- rapid publication on acceptance

- support for research data, including large and complex data types

- gold Open Access which fosters wider collaboration and increased citations

- maximum visibility for your research: over $100 \mathrm{M}$ website views per year

At BMC, research is always in progress.

Learn more biomedcentral.com/submissions 